\title{
The lives of animals' and their relationship to human society
}

\author{
Masayoshi Gondo \\ The Animal Science Hall, Kobe Oji Zoo \\ (3-1, Oji-cho, Nada-ku, Kobe, 657-0838, Japan)
}

\begin{abstract}
Key Words: agricultural chemical pestitides, endocrine disrupting chemicals, food chain, biological concentration, endangered species, extinct in the wild, White Stork
\end{abstract}

(Received: August 24, 2001)

\section{Introduction}

In recent years, interest in the conser vation of the natural environment and the protection of wild animals has been growing, and these issues are receiving more coverage in newspapers and on TV. As I am responsible for the care of many wild animals at my zoo, I have a strong interest in the protection of endangered species.

At the zoo, I have been working on a worldwide network for tasks such as increasing the populations of healthy individuals from some 130 species of animals on the verge of extinction by controlling their bloodlines through breeding, and preserving species for future generations. In particular, I have been responsible for the bloodline registration of tigers in Japan. From this kind of work, I have developed a deep interest in the conditions of animals in the natural environment. Today, I would like to reflect, together with you, on how closely animals in the wild are affected by human activity. What image comes to mind when you hear the word "animal"?

Perhaps you think of insects, fish, amphibians, reptiles, birds or mammals. There are about 1.5 million recognized species in the world. Of these, I think we are especially familiar with birds and mammals. It is said that there are about 8,805 species of birds and 4,080 species of mammals. In Japan, there are about 505 recognized species of birds, including the famous Japanese crested ibis (Niponia nippon) of Sado Island; golden eagles (Aquila chrysaetos), a very small number of which survive in Hyonosen in Hyogo Prefecture; goshawks (Accipiter gentiles), whose survival has become a media issue with the development of mountainous areas; wild geese and ducks, including Hodgson's hawk eagles (Spizaetus nipolensis) that arrive in Japan in winter; whistling swans (Cygnus columbianus) found in Koya Pond in Itami and Kamo Pond in Ono; and Japanese bush warblers (Cettia diphone) and white-eyes (Zosterops japonica) that herald the spring. Until recently, there was also the white stork (Ciconia ciconia), the last of which died in Toyooka, Hyogo Prefecture.

As for mammals, 188 species live in Japan, including the Japanese black bear (Thalarctos maritimus), Japanese serow (Capricornis crispus) , Japanese Sika deer (Cervus nippon), J apanese wild boar (Sus scrofaleucomystax), red fox (Vulpes vulpes), raccoon dog (Nyctereutes procyonoides), marten (Martes melampus), and Japanese squirrel (Sciurus lis). The Japanese archipelago is blessed with 
surprising numbers and diversity of fauna because of the diverse ecosystems stretching from the southern island in the subtropical zone to Hokkaido in the cold zone.

\section{Now, let us consider how the J apanese people related to animals in the past.}

When considering animals in Japan's past, one might think of guardian dogs that kept watch at the gate of a Shinto shrine or foxes as messengers of the Inari deity. Since ancient times, foxes, monkeys, deer, hawks and doves have been treated with respect as divine messengers in the polytheistic J apanese tradition. The J apanese crane is considered a god of happiness, and the proverb about the seeno-evil, hear-no-evil, and speak-no-evil monkeys has been around for generations. In the past, wild animals were a familiar part of daily life, as can be seen in the frequent depiction of animals in art, such as the picture scroll of "The Battle of Twelve" of the M uromachi period, pictures of birds and beasts, and in stories such as "The Fox's Wedding" - and this title has become the expression for a meteorological phenomenon - and in items of daily-use.

Moreover, animal motifs have been used in family crests and emblems, and falconers working with their birds, monkey showmen, and fortune-telling cards chosen by a bird known as the varied tit (Paris varius) were familiar sights until recently.

Until the M eiji era, when Japan became a modern state, the hunting of wild animals was under the control of local feudal lords, which prevented overhunting. It is believed that the White storks (Ciconia ciconia) of Toyooka, which I will talk about later, managed to survive for such a long time thanks to the protection of Lord Izushi and the nature-friendly lifestyle of local farmers. I believe that in many farming villages across Japan, this type of lifestyle was common and resulted in protecting wild animals.

\section{Now, what about people today? What is our relationship with animals like?}

In Tajima, in the northern part of Hyogo Prefecture, there is an increasing number of cases in which bears have been disposed of as dangerous animals when they have appeared too close to people's houses and have eaten and damaged agricultural products in the area. Also, farmers are spending extra money to put up fences to protect mulberry fields from deer and they continue to have problems with troops of monkeys (Macaca) and wild boars that eat and damage their crops.

In Gifu and Nagano Prefectures, damage to trees caused by Japanese serow, animals that have been designated a $\mathrm{N}$ atural $\mathrm{M}$ onument, is a problem. M ore recently, the damage to trees whose bark has been scratched off by bears has become conspicuous. In these ways, the conflict between wild animals believed to live quietly deep in the mountains and people has attracted media attention.

At the same time, we live in an era in which urban dwellers that love the outdoors go to the mountains, looking for contact with wild animals. It is also an age of growing interest in the preservation of the natural environmental and in wild animal protection. Interest in bird watching has grown, evidenced by the appearance of specialized magazines. All sorts of apparatus and tools are available in outdoor equipment shops for bird watchers. M ore and more people can be seen carrying around sophisticated telephotographic cameras. Newspaper articles are also often written about the 
successful feeding of wild boars, raccoon dogs and red foxes.

It is certainly encouraging to know that many people are interested in wild animals. At the same time, however, it is also true that interaction between wild animals and humans has brought about new problems.

\section{Now, let us take a look at the situation from the standpoint of wild animals in J apan.}

The process of the extinction of the white stork of Toyooka demonstrates how our daily lives have evolved and the deep ties we have had with wild animals. During the Tempo years of the Edo period (1830 - 1843), the feudal lord Izushi protected Toyooka's white storks by designating their habitat as a hunting preserve. Their protection continued with the issuance of an Imperial edict in 1892, the promulgation of the Hunting Law in 1908, and the designation of the surviving 30 white storks as Special Natural M onuments in 1921. In 1943, the birds spread, losing their nesting trees as state-owned forests were felled in the midst of intensifying warfare. In 1950, the white storks were designated as a Natural M onument under the Cultural Properties Protection Law.

In 1951, the white stork, as a species, became the object of official protection, which, in addition, gave protection to their habitat. In 1955, the Governor of Hyogo Prefecture established an association for the protection of white storks and initiated civic protection programs. At that time, there were still twenty-three white storks. In 1959, two artificial nesting towers were installed as part of the framework of a protection campaign to "leave the white storks alone." M eanwhile, a one-loach-perperson campaign was launched, and junior high school students in the region began collecting loaches to feed the white storks. In 1963, eggs were collected from their nests for artificial incubation, an attempt that failed. In 1965, individual wild white storks were caught for breeding. Some of these birds subsequently died, which was attributed to mercury poisoning from agricultural chemicals.

In 1985, Khabarovsk, located in the former Soviet Union and a sister province of Hyogo Prefecture, presented Hyogo with six white stork fledglings. In 1989, the twenty-four years of hard work bore fruit in the first successful breeding; the white stork population expanded to 67 individuals. In November 1999, Hyogo Prefectural Homeland for the Oriental White Stork was opened. With this, Hyogo Prefecture was finally able to begin returning the white storks to the wild. You can see from this that the extinction of the white storks coincided with the widespread use of agricultural chemicals, necessitated by the need for increased food production during the post-war restoration period. During that period, as many as 400 tons of organic mercury-based agricultural chemicals were spread each year across Japan to protect paddy-rice plants against blight and harmful insects. You may have heard about the panic that ensued in Japan when traces of chemical pesticides used in agriculture were detected in human milk and hair.

It was also during this period that Rachel Carlson in Silent Spring warned of the danger of agricultural chemicals, and the occurrence of M inamata Disease, a tragic case of illness and birth defects caused by pollution.. As the white storks were feeding on loaches and insects, they were directly exposed to chemical substances that were concentrated in their diet. (Fig. 1) Similarly, golden eagles, relatively large animals, were also exposed to the damaging effects of these chemicals becoming concentrated in their food chain. Deaths of white-tailed eagles (Haliaeetus albicilla) in 


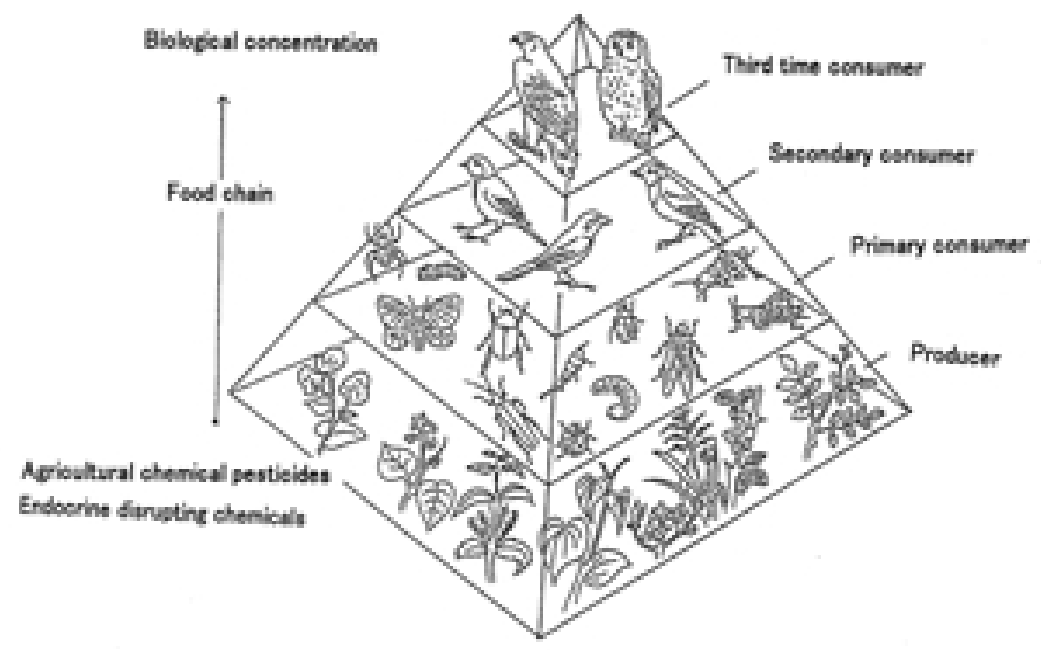

Fig. 1

Hokkaido, due to lead poisoning, as well as the deaths of water birds in a similar situation, have been reported. The lead responsible for these incidents came from bullets used in hunting. Contagious diseases in Japanese serow in the Tohoku region of northern Japan have also been reported; these diseases are usually found in livestock animals.

An example of environmental contamination affecting animals in the wild from overseas, comes from the United States, where the reproduction of crocodiles has been affected because the male individuals are suffering the effects of endocrine disruptors. In Japan as well, we have found that the sea snail, a kind of shellfish, is infected with organo tin compounds, which provoke imposex. In 1996, the American biologist Theo Colborn's Our Stolen Future was published, reporting on research into reproductive abnormalities found among wild animals and proposing that endocrine disrupting chemicals may be responsible. This book has warned us of the emergence of a completely new and grave environmental problem.

\section{Naturally, animals are closely linked to humans.}

We used to think that bears, monkeys, deer, Japanese serow, hawks, eagles and many other wild animals lived quietly, deep in the mountains where people did not go. But now I hope that we understand that these animals are very much present in our community life. Bears come to villages not only because the harvest of nuts is poor in the woods but also because the rich ecosystem that sustains their existence is lacking. The same is true for monkeys. They damage trees because they lack a rich ecosystem. It takes a long time to return animals accustomed to humans back to their original way of living in the mountains because the easy ways of obtaining food are handed down from parents to children.

Even though we may not be conscious of it, animals are being influenced by our economic activities and other factors including Japan's rapid economic development, the ageing population 
inhabiting farm villages, the urbanization of farm villages near cities, single-species tree planting, urban population explosion, and the mass consumption of fossil fuels.

In J apan, at present, 47 species of mammals, 90 species of birds, 18 species of reptiles, 14 species of amphibians, and 76 species of freshwater fish and 245 species of brackish water fish are believed to be in danger of extinction. (Table 1 )

Table 1. The classified table of animal species and Endangered species in Japan.

\begin{tabular}{|c|c|c|c|c|c|c|c|c|c|}
\hline \multicolumn{10}{|c|}{$\begin{array}{c}\text { Endanger Specie } \\
\text { Critically Endangered }\end{array}$} \\
\hline \multirow[t]{2}{*}{ Classified } & \multirow[t]{2}{*}{ Species } & \multicolumn{2}{|c|}{ Extinct } & \multirow[t]{2}{*}{$A$} & & \multirow{2}{*}{\multicolumn{2}{|c|}{$\mathrm{B}$}} & \multirow[b]{2}{*}{ Vulnerable } & \multirow[b]{2}{*}{ Near Threatened } \\
\hline & & wild & & & & & & & \\
\hline \multirow[t]{2}{*}{ M ammalia } & 200 & 4 & 0 & & 31 & & 16 & 16 & 47 \\
\hline & & & & 11 & & 20 & & & \\
\hline \multirow[t]{2}{*}{ Aves } & 700 & 13 & 1 & & 42 & & 48 & 16 & 90 \\
\hline & & & & 17 & & 25 & & & \\
\hline \multirow[t]{2}{*}{ Reptilia } & 97 & 0 & 0 & & 7 & & 11 & 9 & 18 \\
\hline & & & & 2 & & 5 & & & \\
\hline \multirow[t]{2}{*}{ Amphibia } & 64 & 0 & 0 & & 5 & & 9 & 5 & 14 \\
\hline & & & & 1 & & 4 & & & \\
\hline Brackish, & 300 & 3 & 0 & & 58 & & 18 & 12 & 76 \\
\hline River Fish & & & & 29 & & 29 & & & \\
\hline
\end{tabular}

From White Paper of M inistry of Environment on 1999.

Now we are wondering if wild animals in Japan can continue to survive in the future. I'm sure that it is the hope of all of us that they will continue to live, deep in the mountains.

\section{Conclusion}

I would like to continue to reflect with you on our relationship with wild animals, discussing wild birds in the mangroves in M yanmar, which still retains a favorable natural environment, and natural life in Bhutan. Finally, I would like to close my talk by quoting what Father Armand Davis, who introduced the giant panda (Ailuropoda melanoleuca) to the Western world, wrote in 1875 :

\section{References}

- Konotori-no Tanjo; Tajima-no Sora, Inochi Kagayaite (The Birth of White Storks: the Skies of Tajima, a Shining Life), ed. Kobe Shimbun, 1989

- Last Panda; Chugoku-no Chikurin-ni Kieyuku Yasei Dobutsu (The Last Panda: Wild Animals Disappearing in the Chinese Bamboo Groves), George Schaller, Hayakawa Shobo, 1996

— Environment White Paper 1999, Environment Agency, 1999 
動物の生命 - 人間社会との関わり -

権藤眞禎 : 神戶市立王子動物園動物科学資料館（657-0838 神戶市灘区王子町1-3)

我々日本人が過去と現在とでは野生動物との関わりがどのように変遷してきたのか．また，都市と農村 地帯との野生動物に対する接し方の違いを見る. 乥して, 私たちが経済的発展と科学の進歩の恩恵を受け て, 快適な生活を享受してきた影で自然環境が人間社会から排泄されてきた化学物質で污染され, 光の影 響が今後もつづき, 動物たちの生存を脅かすだけでなく，我々人間の健康にも影響を及ぼす恐れか懸念される．

この具体例としてニホンコウノトリ (Ciconia ciconia boyciana) の絶滅した経過と人間社会との関わりを 報告する .

キーワード：農業用化学除草剂, 内分泌かく乱化学物質, 食物連鎖, 生物濃縮, 絶滅危惧種, 絶滅野生種, コウノトリ 